\title{
JUNGIAN ARCHETYPES AND PATRIARCHAL PATTERNS IN WHEN NIETZSCHE
}

\author{
WEPT \\ IRVIN YALOM \\ SIMA FARDIPOUR \\ Department of English, \\ Ahwaz Branch, \\ Islamic Azad University, Ahvaz, Iran \\ DR. PUSHPA V K \\ Associate Professor, \\ Department of English, \\ Ahvaz Branch, \\ Islamic Azad University, Ahvaz, Iran \\ E-mail:pushpaz@yahoo.co.in
}

\begin{abstract}
Archetypes, according to Jung are inborn personal unconscious, and this part of the psyche is truly not individual but 'universal' and in contrast to the personal psyche, it upholds specific contents and modes of behavior that are somewhat same for all individuals living or dead in different space and time zones. Literature is an essential tool for tracing human archetypes, the collective unconscious, and Yalom's novel When Nietzsche Wept as a unique psychological study of fictional and well known historical figures provides the same. The paper investigates the strata of the character's unconscious feelings of toned complexes of their psyche. However, the article also traces the contents of the collective unconscious as the inherent universal part of psychic life known as Archetypes present in the novel. Yalom's When Nietzsche Wept as a fantastic tale of historical figures colliding into each other gives a chance to verify how certain archetypes are universal and even intellectuals and layperson without exception are beholders of such patterns.
\end{abstract}

Keywords: Archetypes, Collective Unconscious, personal psyche, complexes.

\section{INTRODUCTION}

" The primordial image or Archetype is a figure-be it a daemon, or a human being or a process-that constantly recurs in the course of history. In each of these images there is a little piece of human psychology and human fate, a ruminant of the joys and sorrows that have been repeated countless times in our ancestral history,"

Carl Jung Literature is an essential tool for tracing human archetypes, collective unconscious since some works at times present outstanding accounts of historical truth as found in some exceptional works of world literature. Archetypes, according to Jung are inborn personal unconscious, and this part of the psyche is truly not individual but 'universal' and in contrast to the personal psyche, it upholds specific modes of behavior that are somewhat same for all individuals living or dead in different space and time zones. Yalom's creative works, especially his novel When Nietzsche Wept is a unique psychological study of well known historical figures and fictional characters. The paper investigates the strata of the character's unconscious feelings of toned complexes that are part of our mind. However, the article also traces the contents of the collective unconscious as the inherent universal part of the psyche known as Archetypes. Yalom's When Nietzsche Wept is a fantastic tale of historical figures colliding into each other, and it gives a chance to verify how certain archetypes are universal and even intellectuals and laypersons without any exception are beholders of such patterns.

\section{MATERIALS AND METHODS}

Freud and Jung were two pioneers who had undertaken in-depth studies on the hitherto unfathomed realms of human mind for understanding and codifying the complex motivations and reasons that underline human behavior, thought and experience. Gustav Jung (1975-1961), the Swiss analytical psychologist was one of the profound practitioners whose psychological theories were a refined form of Freud's theories on Psychoanalysis which made deep impact on many fields of knowledge, including literature. 
The author of the novel When Nietzsche Wept, Yalom included a special section at the end of his book titled "On Writing a Teaching Novel," where he mentions the inspirational sources of his book together with some of the ideas underlying the novel. Here Yalom allows the readers to become acquainted with psychotherapy, some psychological terminology and the healing process of despair and some psychological problems that afflicted Frederich Nietzsche. In this respect the most appropriate approach to study the psychological working of the mind of the characters and also trace the archetypes inherent in the novel is possibly the elaborate theories of Jungian Archetypes. Some main archetypes, like Hero, Mentor, and Shadow, will also be applied to trace and analyze the Archetypes, Collective Unconscious, and Archetypal images or symbols inherent in the novel. And this research will probe into the historical, philosophical and realistic elements integrated into the novel by the great Psychotherapist.

\section{ARCHETYPES IN LITERATURE}

Archetypes or specific basic human behavior patterns based on human biology are found in many world literature. References to archetypes, collective unconscious, and historical reality, although slightly different in context and meaning have been a favorite theme in world-class writings. Homer's Iliad and Odyssey are the sources of most of Greek legends and myths representing human archetypes. Ancient fables of Aesop fables and the Indian Panchatantra Tales or animal moral stories are all examples of archetypal symbols and images of peaceful coexistence of species. The great Greek tragedies of Sophocles, Euripides and the comedies of Aristophanes are typical examples for the inherent motives of what Jung calls the 'primordial symbols' of 'Collective Unconscious' and human 'archetypes.' The myths and legends of the Greek Hesop and the writings of Roman Ovid are excellent sources of most of our archetypes regarding human belief systems, love, revenge, and relationships. Ovid's Metamorphoses is an inordinate work that narrates the story from the creation of the Earth to the transformation of Caesar into a god and the existence of man in this world. This ingenious poet's Metamorphoses include romantic stories about archetypal images and symbols of birth and death. He is also inventive about afterlife. The Phoenix, a magical bird, reemerges from the ashes and Caesar reincarnates as a star are examples of this visionary poet's reference to archetypes of life after death though Jung lived and formulated such theories many centuries later.

Yalom's novel When Nietzsche Wept throng with historical figures and the plot is constructed based on historical facts. The chain of incidents and the characters at times, appear a replica of their former life. Like Shakespeare's historical plays, the text deals with real events and human dilemmas of Nietzsche and Dr. Breuer.

In modern times, Joseph and his Brothers by Thomas Mann, The Ides of March by Thornton Wilder, The Name of the Rose by Umberto Eco provide other relevant examples of historical works. Some of the contemporary novels by Latin American writers who respond to the social, political constraints of history are The Home of the Spirits (1982) by Isabel Allende and The inhabited Woman (1988) by Gioconda Belli. Margaret Mitchel's Gone with the Wind is a classic example of a novel with historical personalities as it characters like in the Why Nietzsche Wept by Yalom.

What makes When Nietzsche Wept distinctly unique is the characters the reader encounters in this novel are manifestations of Yalom's experience as a therapist together with his in-depth knowledge of existential psychology and philosophy as well as his awareness of the working of human mind. His immaculate portrayal of characters gives a chance to delve into the realms of archetypes inherent in them. The novel narrates a fantastic tale of two dazzling and enigmatic men galloping into each other's psyches which gives reflections of Jungian Archetypes and collective unconscious that reveal the redemptive power of their friendship.

\section{ARCHETYPES AND BASIC HUMAN PATTERNS:}

Cross-Cultural investigations by Anthropologists like Claude Levis Strauss states that individual socio-cultural institutions and behavior patterns exist in all human societies ( Levy 2004) irrespective of certain cultural complexities that may prevail in a particular culture. Family, Marriage, Love, and religion, etc. are such constructs and connections that occur within every culture, though they differ in certain aspects across different cultures.

Psychologically speaking Jung too postulated certain basic concepts of human beings universally present in their "collective unconscious" ( Jung, 1958,1969,1972) regardless of certain peculiarities pertained to individual cultures. According to him, the examples of such 'collective unconscious' concepts are based on his conclusions on extensive cross-cultural field studies ( Van del Post, 1974, Bair, 2003). 


\section{GAP BODHI TARU - $\begin{aligned} & \text { An International Peer-Reviewed } \\ & \text { Open Access Journal of Humanities }\end{aligned}$}

Although the concept of archetypes lies in the cognitive field, in the realm of psychoanalysis (within the unknown complex sphere of human unconsciousness) which is opposite of Anthropology and ethnology studies, the archetypes are manifested many times in observable social behaviors of human beings. ( Jung 1972).These behavior patterns and belief systems aid us in studying the archetypes among people in various cultures as well as among the fictional characters.

The novel When Nietzsche wept reveals the underlying concerns of human beings and particular phenomenon prevail among all cultures like love, distress, friendship, and mental ailments.

The friendship of Nietzsche, Salome, and Paul creates an 'intellectual trinity' or a 'holy trinity' and intellectually they were a 'perfect fit.' Their friendship based on empathy is everyone's needs. This perfect matching they possessed, along with free-thinking and the connection they virtually related through "half-sentences "are the archetypes that can bond people beyond cultures.

Jung's conception of archetypes is closely tied into his theory of the collective unconscious, an overarching "second psychic system of a collective, universal, and impersonal nature which is identical in all individuals" (Jung, The Concept of the Collective, 43). Such archetypes can be traced in various parts of this novel. For example, the Archetype Mentor as follows:

One of the renowned Archetypes the Mentor is "The Mentor provides motivation, insights, and training to help the Hero" is quite applicable here. The close friendship between Nietzsche and Dr. Breuer is one of such relationships. The novel demonstrates how the roles of the therapist and patient blur when the fictional Nietzsche starts to take notes about Dr. Breuer's obsessions and how he can best help him, turning the great philosopher into a healer or a therapist. And the process goes vice versa.

Since Yalom wrote this novel based on his case studies, we can certainly presume that such incidents are part of his experiences during his own professional practice as a psychotherapist. Not only this, Yalom repeatedly refers to his intense passion for stories of old healers especially the one found in Hermann Hess's novel Magister Ludi. The story narrates the deep friendship of two renowned healers and indirectly touches on the nature of the patient-therapist relationship. In his own words, ".. the echoes of these tales ring throughout the pages of the novel." Yalom's remarks about friendship are quoted in Nowacka that there occurs a change from neediness to needlessness in relationship, friendship is a healer in one's journey of life (qtd.in Nowacka)

Archetypes are innate universal pre-conscious psychic dispositions that form the substrate from which the underlying themes of human life emerge. When Nietzsche Wept too proclaims the intricacies of human nature, death. "Death is devastating" and a brave Physician like Dr. Breuer is "cynical about the patients." They find it tough to digest the mystery of death, even when they are not entangled by any theistic dogmas of fate, destiny, heaven, hell or the afterlife. Death is painful and hurting, and this primordial motif of death referred to is intriguing for all. Dr. Breuer and other physicians who help patients in their last stages of life to face death peacefully are not exempted from this intriguing universal concept and pain of death.

Prejudices or biased attitudes are trigged by the mentality of certain people, like the notorious Nazi's hatred of Jews, which still exists in some cultures. It can rupture friendship, morality and even human values. Yalom discusses the devastating state or the "spiritually impoverished" stage when prejudices predominate individual psyches. It is this prejudice instilled by the destructive influence of his mother and sister Elizabeth that made Nietzsche and Paul separate, leaving a "hatred ruptured friendship." Impact of Elizabeth's hatred on Nietzsche is visible as the agitation imprinted in his letters. "Nietzsche's love is turned to hatred." There is a parallel relationship between archetypes and DNA as Stevens (1982) suggests that ethology and analytical Psychology are related in comprehending certain universal phenomena as Ethology demonstrates how certain species display unique behavior patterns when adapted to their peculiar environments and how we are influenced and adapted to certain conditions. Stevens pointed out how genetically programmed behavior is taking place on psychological level as in the psychological relationship of mother and newborn. The baby's helplessness and repertoire of sign stimuli and approach behavior trigger maternal care response and the very smell, and similarly, the sound of mother triggers a feeding response on the part of the infant. Transmission of archetypes occurs wherever life is found. Savagery and prejudices go on all over the world irrespective of the cultural peculiarities. Hatred against Jews, apartheid and divisions in the name of race and caste are still practiced as if they become archetypes of collective unconscious of many people. Yalom's novel When Nietzsche Wept touches on these precarious archetypes of "spiritual impoverishment" in many cultures. 


\section{PATRIARCHAL PATTERNS AND FEMININE ARCHETYPES}

Archetypes are instincts. They are based on human being's biology and basic needs to some extent. None is exempted from the requirements, even a great Physician and historical figure like Dr. Breuer.

According to Jung, the anima archetype appears in all men, and it is the primordial image of the woman. Anima refers to man's sexual expectation of women and the sharp analogous image of feminine that occurs in men. The truth is that most often this anima archetype is a symbol of man's possibilities and his contrasexual tendencies. The opening scene of the novel denotes this anima of Dr. Breuer. Though his visitor Salome was in her early twenties and looked almost like a teenager, Dr. Breuer's initial impulse was to possess her. He felt her beauty 'damage his soul' as Bertha did to him. He met Salome for the first time and does not know much about this 'school girl' looking girl, but he was sexually attracted to her and aroused his sexual feeling even though she came to visit him on a special mission to get appointment for treatment for a patient with' deteriorating physical health.'

It is a truth that "each woman brought vibrations into his loins' and like a patriarch, he feels his superiority and considers 'women as weary creatures.' He always had 'carnal thoughts of Bertha.' And these sexual thoughts of anima entangled him into the labyrinth of complicated relationships with his patient who was suffering from intense despair, and he tried to get her treated applying his unique technique of mesmerism. His thoughts and behavior appear to some extent as nothing but this primary anima archetype of man and his basic sexual instinct towards a woman based on human biology and needs. To Dr. Breuer, Bertha symbolizes all women, attractive, beautiful, sexually stimulating and 'brought vibrations to his loins.' Therefore, Archetypes are instincts and no man even Dr. Breuver is exempted from individual sexual abilities and his intense desire for opposite sex.

Philosophers, Psychologists, Sociologists, anthropologists, historians, and even laypersons were fascinated and intrigued by the unique behavior patterns, preferences, fluctuating thoughts, choices and decisions of human beings, though human beings are the only creatures on earth endowed with the blessings of rational thoughts and decision making. Intriguingly, even an intelligent, composed, well-reputed individual at certain moments may slip away from his standard characteristics and commit blunders, behave meanly or display a different response to his normal continence. Why such follies and hamartia occur? Why do some suffer from distress and dismay in spite all their knowledge and experience? It has been a topic appalled men for centuries and figured in many world literature. Classical literature, especially the Greek tragedies, Shakespearian dramas and much modern work of arts probe into the shadow archetypes i.e. the dark depths of human unconscious and investigate human predicaments and suffering due to some simple follies or mistakes.

Nietzsche, the great philosopher with all his vast reservoir of knowledge, critical -rational thinking, and grandiose existential philosophy, is not exempted from such follies and suffering. What dismay him? What is the pitfall? By applying Jung's archetypes aids to trace the behavior patterns and Collective Unconscious implicit Why Nietzsche Wept. 'Salome is the reason for his despair.' Nietzsche is caught in this whirlpool of basic instincts related to the primordial images of women. And it sounds strange he 'proposed marriage at his first meeting' to a girl for whom 'marriage was a tyranny 'and was a friend of his student.

Apart from revealing the intricacies of the human mind, archetypes, and Collective Unconscious, the novel also exposes certain historical elements and philosophies regarding marriage, death, and woman. The philosopher and the physician contemplate certain patriarchal ideologies regarding women. Like Freud Nietzsche and Dr. Breuer consider the idea that "women as topics of physical carnal pleasure"; "women as weary Creatures"; women are source of "enchantment" and naturally want to "merge with them." Dr. Breuer's "sexual thoughts towards Salome" and Nietzsche's insistence on marrying a 'school girl' looking young student who thinks "marriage is a tyranny" are typical examples of the patriarchal thoughts of possession and women as objects of sexual desires.

\section{RESULTS AND DISCUSSION}

To illuminate the motives of different behavior patterns certain important concepts and archetypes which are interrelated to them especially Freudian and Jungian theories are applied here. Many modern psychoanalytical and neurological facts as well as Ethnology and are referred to analyze characters like Nietzsche, Dr. Breuer and Lou Andreas Salome, The present work tried to identify unique behavior patterns and estimate as well as evaluate the prospects of applying or identifying them in other contexts. 
The character traits and behavior patterns of Nietzsche and Dr. Breuver unravel the hidden labyrinths of human Unconscious and retrieve the concealed universal Archetypes inherent in When Nietzsche Wept.Since the novel is an exquisite study of the inner working of the mind of the characters and the obsessions, distress and internal conflicts of some well-known historical figures by a learned Psychoanalyst, we reach to better results by analyzing the characters using the Jungian theories of Archetypes and concepts of Existential psychology.

\section{CONCLUSIONS}

The author manipulates two high caliber topics of the modern world, Psychoanalysis, and Philosophy in this novel while many historical figures parades ahead through Yalom's fictional characters. These characters come alive for the readers as real human beings, especially through the portrayal of the renowned German Philosopher of 20th Century in this novel, which provides an opportunity to trace universal archetypes and Collective Unconscious inherent in this novel. Apart from this great philosopher, other historical figures appear here with their real names, and the plot is constructed around many well documented historical facts and figures that seem to be the replica of the original. This genre can be molded only at the hands of a skillful historical researcher who has a profound sense of historical perception, fictional talents and a deep awareness of the psychological working of human mind.

Many concealed motives of different behavior patterns are illuminated here by the application of Freudian and Jungian theories and many modern psychoanalytical and neurological concepts to analyze characters like Nietzsche, Dr. Breuer, and Lou Andreas Salome. The present work tried to identify unique behavior patterns and estimate as well as evaluate the prospects of applying or identifying them in other contexts as well.

This novel has demonstrated the role of universal archetypes on human history and development. The author has emphasized love and the role of friendship in human life especially when life is in despair Also; this friendship has evolved out of the character's thoughts in the form of empathy, care, and understanding throughout the story, which is the fundamental ingredient for peaceful human existence.

\section{REFERENCES}

Allen, James Lovic. "Unity of Archetype, Myth, and Religious Imagery in the Work of

$>$ Yeats." Twentieth-Century Literature 20.2 (1974): 91-95.

$>$ Benziman, Galia, Ruth Kannai, and Ayesha Ahmad. "The Wounded Healer as Cultural Archetype." Clcweb: Comparative Literature \& Culture: A WWWeb Journal 14.1 (2012): 1-9.

$>$ Edinger, Edward F. Ego, and archetype: individuation and the religious function of the

$>$ psyche. New York, NY: Putnam, 1972

$>$ Freud, Sigmund. The Interpretation of Dreams. James Strachey, trans. And ed. Eighth edition, Third (revised) English edition. New York, NY: Basic Books, 2010.

$>$ Garry, Jane, and Hasan M. El-Shamy, eds. Archetypes and Motifs in Folklore and Literature: A Handbook. Armonk, NY: M.E. Sharpe, 2005.

$>$ Goodwyn, Erik. "Approaching archetypes: reconsidering innateness." Journal of Analytical Psychology 55 (2010): 502-521.

$>$ Jung, C. G. "Approaching the Unconscious." Located in Man and His Symbols. Carl G. Jung and M.-L. Von Franz, eds. London, UK: Aldus Books, 1964.

> Jung, C. G. "Archetypes of the Collective Unconscious." Located in The Archetypes and the Collective Unconscious. R.F.C. Hull, trans. Second edition, Tenth printing. New York, NY: Princeton University Press, 1990.

$>$ Kirkegaard. "Existentialism." Def. 1. Urban Dictionary. N.p., Mar. 2005. Web. 18 Oct. 2013.

$>$ Park, James. "Our Existential Predicament: Loneliness, Depression, Anxiety \& Death."TC.UMN.edu.University of Minnesota, n.d. Web. 11 Dec. 2013.

$>$ Yalom, Irvin D. When Nietzsche Wept. New York, NY: Basic, 1992. Print 